\title{
Penerapan Asas Ultimum Remidium dalam Penegakan Hukum Pidana di Bidang Cukai
}

\section{Indrawati ${ }^{1}$, Bendito Menezes $^{2}$}

${ }^{1}$ Indrawati; Fakultas Hukum Universitas Merdeka Malang; Jl. Terusan Dieng No.62-64; Malang; 65115; Indonesia.

${ }^{2}$ Bendito Menezes; Kantor Bea Cukai Malang; Jl. Surabaya No. 2; Malang; 65145; Indonesia.

\section{ARTICLEINFO}

Article history:

Received 2018-03-14

Received in revised form

2018-04-19

Accepted 2018-06-01

Kata kunci:

Ultimum Remidium, Tindak Pidana

Cukai, dan Penegakan Hukum.

\section{Keywords:}

Ultimum Remedium, Excise Crime, and Law Enforcement.
Corresponding Author:

Bendito Menezes

E-mail address: danielladito@yahoo.com

DOI: https://doi.org/10.26905/idjch.v9i1.2118

\section{Abstrak}

Upaya keras dalam penegakan undang-undang cukai, sanksi pidana digunakan sebagai alat untuk memberikan daya paksa yang maksimal bagi masyarakat wajib cukai. Namun sejatinya ketentuan pidana adalah upaya terakhir manakala sanksisanksi andministrasi tidak lagi bekerja secara optimal. Penelitian ini menggunakan Metode Penelitian hukum normatif. Suatu pelanggaran untuk dapat dikategorikan sebagai tindak pidana tidak lepas dari legalitas dari subyek hukum yaitu pengusaha BKC maupun obyek hukum yaitu BKC dan Pita Cukai. Bilamana salah satu dari subyek hukum atau obyek hukum bersifat ilegal, maka pelanggaran yang dilakukannya tersebut adalah suatu bentuk tindak pidana. Disamping itu, suatu perbuatan dapat dipidana berdasarkan undang-undang Cukai apabila memenuhi kriteria sebagai berikut: dirumuskan secara tegas dan jelas sebagai pelanggaran, secara nyata menimbulkan kerugian negara, dan merupakan perbuatan yang berulang, atau kerugian negara yang ditimbulkan tidak dapat diperbaiki. Penerapan asas ultimum remidium dalam penegakan hukum di bidang cukai perlu menggunakan teori restorative justice untuk merestorasi kerugian negara yang ditimbulkan oleh para pelaku tindak pidana di bidang cukai, dan teori social cost untuk memberikan tambahan biaya dan resiko yang ditanggung oleh para pelaku kejahatan agar mereka mengurungkan niat melakukan kejahatan.

\section{Abstract}

Strict efforts in enforcing excise laws, criminal sanctions are used as a tool to provide maximum forced power for the excise duty community. But the truth is that criminal provisions are the last resort when administrative sanctions no longer work optimally. This study uses normative legal research methods. An offense to be categorized as a criminal offense cannot be separated from the legality of the legal 
subject, namely the BKC businessman and the legal object, namely the BKC and the Excise $B a n d$. If one of the legal subjects or legal object is illegal, then the violation committed is a form of criminal offense. In addition, an act can be convicted under the Customs law if it meets the following criteria: explicitly and clearly formulated as a violation, significantly causing state losses, and is a recurring act, or state losses incurred cannot be repaired. The application of the principle of ultimum remidium in law enforcement in the excise sector needs to use the theory of restorative justice to restore state losses caused by criminal offenders in the excise field, and social cost theory to provide additional costs and risks for criminals to dissuade them commit crime.

\section{Latar Belakang}

Undang-Undang Cukai dapat ditemukan dua instrumen untuk penegakan hukumnya meliputi pengawasan dan penegakan sanksi. Pengawasan merupakan langkah preventif dan penerapan sanksi sebagai langkah represif untuk memaksakan kepatuhan (Ridwan, 2014). Sebagai Undang-Undang fiskal, maka fungsi utama dari penerapan UndangUndang Cukai adalah bagaimana membuat para wajib pajak atau wajib Cukai mematuhi segala ketentuan yang diatur dan melaksanakan kewajiban melalui pembayaran Cukai guna tercapainya penerimaan Negara yang maksimal.

Melihat bahwa begitu pentingnya penerimaan Negara dari sector penerimaan Cukai dalam rangka menggerakkan perekonomian, maka sebagai upaya keras dalam penegakan UndangUndang Cukai, maka sanksi pidana digunakan untuk memberikan daya paksa yang maksimal bagi masyarakat wajib Cukai. Namun sejatinya ketentuan pidana yang ada didalam Undang-Undang Cukai adalah jalan terakhir yang digunakan untuk memaksakan kepatuhan manakala sanksi-sanksi andministrasi tidak lagi bekerja secara optimal.

Melihat fenomena yang terjadi dalam Praktik penerapan sanksi dalam Undang-Undang Cukai, dimana sanksi pidana dan sanksi administrasi berdiri secara sejajar, padahal seharusnya penerapan sanksi pidana harus mengacu pada asas Ultimum Remidium maka penulis berkeyakinan bahwa perlu suatu penelitian yang dapat memberikan jawaban atas persoalan-persoalan diatas.

Permasalahan-permasalahan yang perlu mendapatkan jawaban melalui penelitian ini adalah apa kriteria-kriteria perbuatan yang dapat diberi sanksi administrasi dan sanksi pidana dan bagaimana menerapkan asasultimum remidium dalam penegakan hukum di bidang Cukai. Adapun metode penelitian yang digunakan adalah Penelitian hukum normatif yaitu jenis penelitian yang digunakan untuk menemukan dan mengumpulkan serta mengolah bahan hukum. Jenis penelitian ini digunakan dengan maksud melakukan analisis terhadap ketentuan-ketentuan pidana dalam Undang-Undang Cukai, bagaimana ketentuan-ketentuan itu dijiwai oleh asas ultimum remidium, bagaimana melakukan pembaharuan terhadap ketentuan-ketentuan pidana dalam Undang-Undang Cukai dengan menentukan kriteria-kriteria perbuatan yang dapat diberi sanksi administrasi dan sanksi pidana.

\section{Metode}

Jenis penelitian dalamlmenggunakan penelitian normatif-empiris. Penelitian normatif-empiris yaitu penelitian yang dilakukan untuk menelaah kaidah hukum normatif yang dilihat dari segi penerapannya. Penelitian normatif-empiris ini dilakukan untuk mencermati bagaimana ketentuan-ketentuan itu dijiwai oleh asas ultimum remidium, bagaimana melakukan pembaharuan terhadap 


\section{Penerapan Asas Ultimum Remidium dalam Penegakan Hukum Pidana di Bidang Cukai \\ Indrawati \& Bendito Menezes}

ketentuan-ketentuan pidana dalam UndangUndang Cukai dengan menentukan kriteria-kriteria perbuatan yang dapat diberi sanksi administrasi dan sanksi pidana.

Dengan mempertimbangkan perspektif yang digunakan dalam mengkaji penerapan asas ultimum remidium dalam penegakan hukum pidana di bidang cukai pada penelitian ini menggunakan pendekatan yuridis normatif-empiris dengan studi kasus hukum (judicial case study). Penelitian ini menggunakan pendekatan yuridis karena berpijak pada ketentuan-ketentuan hukum di bidang cukai nasional sebagai dasar normatif, sedangkan pendekatan unsur empiris, karena dalam penelitian ini melakukan peninjauan pelaksanaan ketentuan yuridis tersebut, termasuk mengkaji beberapa hal yang berpengaruh pada pelaksanaan ketentuan hukum yang berlaku di masyarakat di telaah dari sisi empiris.

\section{Pembahasan}

Undang-Undang Cukai, telah diatur mengenai perbuatan-perbuatan yang dikategorikan sebagai pelanggaran administrasi maupun perbuatan-perbuatan yang dikategorikan sebagai tindak pidana. Secara umum, pelanggaran dalam Undang-Undang Cukai digolongkan sebagai Mala prohibita atau malum prohibitum, yang berarti bahwa perbuatan tersebut tergolong sebagai kejahatan karena diatur demikian oleh Undang-Undang. Sebagai Mala prohibita, maka perbuatan tersebut harus dirumuskan secara jelas dalam Undang-Undang agar dapat dipahami dengan baik oleh masyarakat luas.

Ada dua aspek penting yang dapat digunakan sebagai penentu ketika melakukan penggolongan suatu tindakan atau perbuatan sebagai pelanggaran administrasi atau tindak pidana. Kedua hal tersebut adalah legalitas dari subyek hukum dalam hal ini pelaku usaha atau yang diatur dalam Undang-Undang Cukai adalah pengusaha BKC (barang kena cukai) dan obyek hukum yaitu BKC (barang kena cukai) dan Pita Cukai itu sendiri sebagai tanda pelunasan Cukai. Dalam rumusan pasal yang mengatur pelanggaran administrasi, subyek hukumnya adalah pengusaha BKC (barang kena cukai) sebagaimana diatur dalam pasal 14 ayat (1) Undang-Undang Cukai dengan obyek hukumnya berupa BKC (barang kena cukai) dan Pita Cukai atau tanda pelunasan lainnya sebagaimana diatur dalam pasal 29 Undang-Undang Cukai. Sedangkan dalam rumusan pasal yang mengatur tentang tindak pidana, subyek hukumnya adalah setiap orang yang berarti tidak hanya terbatas pada pengusaha BKC (barang kena cukai) dengan obyek hukum berupa BKC (barang kena cukai) dan Pita Cukai atau tanda pelunasan Cukai lainnya. Hubungan antara subyek hukum dan obyek hukum dapat dijelaskan bahwa apabila salah satu dari subyek hukum atau obyek hukum bersifat ilegal yaitu tidak memenuhi syarat legalitas (perijinan) sesuai pasal 14 ayat (1) Undang-Undang Cukai atau tidak memenuhi kewajiban pelunasan Cukai sebagaimana diatur dalam pasal 29 Undang-Undang Cukai maka pelanggaran yang dilakukan tersebut adalah suatu bentuk tindak pidana.

Pelanggaran Administrasi pada prinsipnya adalah bentuk pelanggaran terkait dengan formalitas atau prosedural, dimana secara prinsip kewajiban Cukai telah dipenuhi atau dalam proses pemenuhan kewajiban, tetapi belum atau kurang dalam memenuhi syarat formal atau prosedural terkait penggunaan fasilitas Cukai, pelaporan, pembukuan, pencatatan, pengeluaran, pemasukan dan pengangkutan. Sedangkan tindak pidana adalah bentuk pelanggaran yang bersifat materiil yaitu terkait dengan legalitas dari Cukai itu sendiri. Artinya suatu perbuatan yang semata-mata dilakukan untuk menghindari pembayaran Cukai dengan cara atau dalih apapun yang pada akhirnya menyebabkan tidak terpungutnya Cukai yang menimbulkan kerugian Negara.

Apabila ditelaah secara mendalam, dapat ditemukan bahwa diantara pasal-pasal yang mengatur tentang pelanggaran administrasi dan pasal-pasal 
yang mengatur tentang tindak pidana memiliki keterkaitan yang sangat erat satu sama lain. Perbuatan-perbuatan yang di kategorikan sebagai pelanggaran administrasi di satu sisi adalah juga perbuatan-perbuatan yang digolongkan sebagai tindak pidana di sisi lain. Sebagai contoh Rumusan pasal 50 Undang-Undang Cukai menyatakan: “Setiap orang yang tanpa memiliki izin sebagaimana dimaksud dalam Pasal 14 menjalankan kegiatan pabrik, tempat penyimpanan, atau mengimpor BKC (barang kena cukai) dengan maksud mengelakkan pembayaran Cukai dipidana dengan pidana penjara paling singkat 1 (satu) tahun dan paling lama 5 (lima) tahun dan pidana denda paling sedikit 2 (dua) kali nilai Cukai dan paling banyak 10 (sepuluh) kali nilai Cukai yang seharusnya dibayar".

Rumusan pasal ini memiliki kesamaan apabila dibandingkan dengan rumusan pasal 14 ayat (7) Undang-Undang Cukai yang menyatakan: "Setiap orang yang menjalankan kegiatan sebagaimana dimaksud pada ayat (1) tanpa memiliki izin dikenai sanksi administrasi berupa denda paling sedikit Rp 20.000.000,00 (dua puluh juta rupiah) dan paling banyak Rp 200.000.000,00 (dua ratus juta rupiah).

Dalam rumusan kedua pasal ini, subyek hukumnya secara sama melakukan kegiatan sebagai pengusaha BKC (barang kena cukai) dengan tidak memiliki ijin, tetapi dikategorikan secara berbeda oleh karena pada pasal 50 Undang-Undang Cukai terdapat rumusan dengan maksud mengelakkan Cukai. Bilamana dicermati dengan seksama, rumusan dalam pasal 14 ayat (7) Undang-Undang Cukai yang mengatur tentang pengenaan sanksi administrasi berupa denda paling sedikit Rp 20.000.000,00 (dua puluh juta rupiah) dan paling banyak Rp 200.000.000,00 (dua ratus juta rupiah) memberikan makna bahwa pelanggaran tersebut dimungkinkan terjadi secara berulang kali, sehingga dapat dipastikan bahwa pengulangan perbuatan berarti juga terdapat maksud dari pelang- gar untuk mengelakkan Cukai atau menghindari untuk tidak membayar Cukai.

Apabila mens rea dijadikan sebagai parameter, maka pelanggaran yang diatur pasal 14 ayat (7) Undang-Undang Cukai tidak seharusnya dikategorikan sebagai pelanggaran administrasi bilamana pelanggaran tersebut adalah pelanggaran yang berulang, atau tindak pidana yang diatur dalam pasal 50 Undang-Undang Cukai tidak semestinya dikategorikan sebagai tindak pidana, jikalau tindak pidana tersebut dilakukan untuk pertama kalinya.

Rumusan pasal 52 Undang-Undang Cukai yang menyatakan: "pengusaha pabrik atau pengusaha tempat penyimpanan yang mengeluarkan Barang Kena Cukai dari pabrik atau tempat penyimpanan tanpa mengindahkan ketentuan sebagaimana dimaksud dalam Pasal 25 ayat (1) dengan maksud mengelakkan pembayaran Cukai dipidana dengan pidana penjara paling singkat 1 (satu) tahun dan paling lama 5 (lima) tahun dan pidana denda paling sedikit 2 (dua) kali nilai Cukai dan paling banyak 10 (sepuluh) kali nilai Cukai yang seharusnya dibayar".

Rumusan pasal ini, serupa dengan rumusan pasal 25 ayat (4) yang menyatakan: "pengusaha pabrik atau pengusaha tempat penyimpanan yang mengeluarkan Barang Kena Cukai dari pabrik atau tempat penyimpanan, yang tidak melaksanakan ketentuan sebagaimana dimaksud pada ayat (1) dikenai sanksi administrasi berupa denda sebesar 2 (dua) kali nilai Cukai dari Barang Kena Cukai yang dikeluarkan".

Hal yang membedakan rumusan pada kedua pasal tersebut adalah pada rumusan kata dengan maksud mengelakkan Cukai. Untuk mendefinisikan makna dari kata dengan maksud mengelakkan Cukai tersebut, bukanlah hal yang mudah. Perlu diberikan parameter-parameter yang jelas agar dalam penegakannya tidak terjadi diskriminasi karena semata-mata tergantung pada pemahaman penegak hukum. 


\section{Penerapan Asas Ultimum Remidium dalam Penegakan Hukum Pidana di Bidang Cukai}

Indrawati \& Bendito Menezes

Rumusan pasal 53 Undang-Undang Cukai menyatakan: "Setiap orang yang dengan sengaja memperlihatkan atau menyerahkan buku, catatan, dan/atau dokumen, sebagaimana dimaksud dalam Pasal 36 ayat (1) atau laporan keuangan, buku, catatan dan dokumen yang menjadi bukti dasar pembukuan, dan dokumen lain yang berkaitan dengan kegiatan usaha, termasuk data elektronik serta surat yang berkaitan dengan kegiatan di bidang Cukai sebagaimana dimaksud dalam Pasal 39 ayat (1b) yang palsu atau dipalsukan, dipidana dengan pidana penjara paling singkat 1 (satu) tahun dan paling lama 6 (enam) tahun dan pidana denda paling sedikit Rp 75.000.000,00 (tujuh puluh lima juta rupiah) dan paling banyak Rp 750.000.000,00 (tujuh ratus lima puluh juta rupiah)".

Rumusan pasal ini dapat bandingkan dengan rumusan pasal 36 ayat (2) Undang-Undang Cukai yang menyatakan: "Pengusaha pabrik, pengusaha tempat penyimpanan, importir Barang Kena Cukai, penyalur, pengusaha tempat penjualan eceran, pengguna Barang Kena Cukai yang mendapatkan fasilitas pembebasan Cukai sebagaimana dimaksud dalam Pasal 9, yang terhadapnya dilakukan pemeriksaan, yang tidak menyediakan tenaga atau peralatan atau tidak menyerahkan buku, catatan, dan/ atau dokumen pada waktu dilakukan pemeriksaan sebagaimana dimaksud pada ayat (1) dikenai sanksi administrasi berupa denda paling sedikit Rp 25.000.000,00 dua puluh lima juta rupiah) dan paling banyak Rp 250.000.000,00 (dua ratus lima puluh juta rupiah)".

Rumusan pasal 39 ayat (2) Undang-Undang Cukai yang menyatakan: "Setiap orang yang menyebabkan pejabat bea dan Cukai tidak dapat menjalankan kewenangan audit Cukai dikenai sanksi administrasi berupa denda sebesar $\mathrm{Rp}$ 75.000.000,00 (tujuh puluh lima juta rupiah)". Selanjutnya Rumusan pasal 16 ayat (4) Undang-Undang Cukai yang menyatakan: "Pengusaha pabrik, pengusaha tempat penyimpanan, importir Barang Kena Cukai, atau penyalur yang wajib memiliki izin, yang tidak menyelenggarakan pembukuan sebagaimana dimaksud pada ayat (1) dikenai sanksi administrasi berupa denda sebesar Rp50.000.000,00 (lima puluh juta rupiah)".

Rumusan pasal 16 ayat (5) Undang-Undang Cukai yang menyatakan: "Pengusaha pabrik skala kecil, penyalur skala kecil yang wajib memiliki izin, dan pengusaha tempat penjualan eceran yang wajib memiliki izin, yang tidak melakukan pencatatan sebagaimana dimaksud pada ayat (2) dikenai sanksi administrasi berupa denda sebesar Rp10.000.000,00 (sepuluh juta rupiah). Selanjutnya Rumusan pasal 16 B Undang-Undang Cukai yang menyatakan: "bahwa Pengusaha pabrik, pengusaha tempat penyimpanan, importir Barang Kena Cukai, atau penyalur yang wajib memiliki izin, yang tidak melaksanakan ketentuan sebagaimana dimaksud dalam Pasal 16A dikenai sanksi administrasi berupa denda sebesar Rp25.000.000,00 (dua puluh lima juta rupiah)".

Hal yang membedakan dan memberatkan dalam rumusan pasal 53 Undang-Undang Cukai adalah pada rumusan kalimat yang palsu atau dipalsukan. Sepintas membaca rumusan pasal ini, maka dapat dimengerti bahwa perbuatan ini layak untuk dipidana. Akan tetapi manakala dilakukan telaah dan analisa mendalam dengan membandingkannya dengan rumusan pasal 36 ayat (2) Undang-Undang Cukai, pasal 39 ayat (2) UndangUndang Cukai, pasal 16 ayat (4) Undang-Undang Cukai, pasal 16 ayat (5) Undang-Undang Cukai, dan pasal 16B Undang-Undang Cukai, maka nampak bahwa mengaktegorikan rumusan pasal 53 sebagai tindak pidana kurang tepat karena menurut penulis, manakala perbuatan tidak melakukan pencatatan, tidak menyelenggarakan pembukuan, tidak menyimpan dokumen, tidak menyimpan laporan keuangan, tidak menyediakan tenaga atau peralatan atau tidak menyerahkan buku, catatan, dan/atau dokumen pada waktu dilakukan pemeriksaan, atau menyebabkan pejabat bea dan Cukai tidak dapat menjalankan kewenangan audit Cukai hanya dikenakan sanksi administrasi. 
Maka menjadi tidak adil manakala orang yang memperlihatkan atau menyerahkan buku, catatan, dan/atau dokumen, sebagaimana dimaksud dalam Pasal 36 ayat (1) Undang-Undang Cukai atau laporan keuangan, buku, catatan dan dokumen yang menjadi bukti dasar pembukuan, dan dokumen lain yang berkaitan dengan kegiatan usaha, termasuk data elektronik serta surat yang berkaitan dengan kegiatan di bidang Cukai sebagaimana dimaksud dalam Pasal 39 ayat (1b) UndangUndang Cukai yang palsu atau dipalsukan harus dipidanakan. Hal ini dapat membentuk opini umum bahwa adalah lebih baik tidak membuat sama sekali dari pada membuat tetapi dengan cara memalsukan.

Masalah sentral kebijakan kriminal dalam menggunakan hukum pidana ialah masalah penentuan tentang perbuatan apa yang seharusnya dijadikan tindak pidana dan sanksi apa yang sebaiknya digunakan atau dikenakan kepada si pelanggar (Arief, 1994). Dalam kaitannya dengan hal tersebut, Undang-Undang Cukai telah menempatkan sanksi pidana sebagai sanksi yang digunakan untuk memberikan tekanan bagi kepatuhan wajib Cukai, namun perlu dibuat suatu parameter yang menjadi pedoman dalam penerapannya. Dalam kaitannya dengan semangat menjadikan hukum pidana sebagai ultimum remidium, maka perlu dicantumkan rumusan yang memiliki semangat untuk meletakkan hukum pidana sebagai langkah terakhir.

Dalam pemikiran penulis, suatu perbuatan yang dapat dipidana harus memenuhi criteria; (1) Rumusannya tegas dan jelas sebagai pelanggaran agar mudah dipahami dan mengandung satu interpretasi agar tidak terjadi salah penerapan hukum atau perdebatan yang tidak perlu, (2) Menimbulkan kerugian Negara, dan (3) Perbuatan yang berulang untuk memberikan parameter yang tegas mengenai kapan suatu perbuatan itu dapat dipidana. Perbuatan yang berulang juga mengandung makna bahwa pendekatan hukum lainnya tidak memberikan efek jera bagi pelaku, sehingga perlu pendekatan yang lebih tegas yaitu melalui pidana (ultimum remidium), atau (4) Kerugian yang ditimbulkan tidak dapat diperbaiki, agar tidak memunculkan suatu kondisi dimana seorang pelanggar tidak mendapatkan sanksi atas kesalahan yang telah dilakukannya.

Undang-Undang Cukai sebagai hukum administrasi Negara yang secara fungsi menjadi alat Negara untuk menjalankan kebijakan di bidang fiskal, pada kenyataannya tidak selalu sejalan dengan tujuan penegakan hukumnya. Meskipun dalam Undang-Undang Cukai mengisyaratkan tentang fungsi perlindungan masyakarat, tetapi pada kenyataannya fungsi yang paling menonjol adalah fungsi penerimaan. Penegakan hukum yang dilakukan adalah bagaimana memastikan kepatuhan masyarakat dalam melakukan kewajiban Cukainya dan memastikan terpenuhinya penerimaan Negara dari sektor Cukai.

Berdasarkan penjelasan tersebut diatas, maka dapat dibuat rumusan tentang apa sesungguhnya tujuan dari penegakan hukum dan pengenaan sanksi dalam Undang-Undang Cukai yaitu bagaimana mencegah terjadinya pelanggaran dengan mengenakan sanksi yang berat, dan memperbaiki kerugian yang telah ditimbulkan melalui pengenaan denda yang berlapis. Tetapi dalam kenyataannya, seringkali terjadi pengulangan perbuatan dan kegagalan dalam merestorasi kerugian Negara. Hal ini menurut penulis terjadi oleh karena sarana yang digunakan dalam penegakan hukum, dalam hal ini sanksi pidananya tidak efektif.

Setelah memperhatikan penjelasan terkait kriteria-kriteria diatas, maka dapat dibuat rumusan pasal yang dijiwai oleh kriteria-kriteria tersebut yang dapat memberikan kejelasan dan ketepatan dalam penerapannya. Sebagai contoh pasal 50 dan pasal 14 ayat (7) Undang-Undang Cukai digabungkan dalam satu pasal dengan rumusan sebagai berikut: Setiap orang yang tanpa ijin menjalankan kegiatan sebagai: Pengusaha pabrik; Pengusaha tempat penyimpanan; Penyalur; Tempat penjual eceran; atau Importir. 
Barang Kena Cukai, dipidana dengan pidana penjara paling singkat 1 (satu) tahun dan paling lama 5 (lima) tahun dan pidana denda paling sedikit 2 (dua) kali dan paling banyak 10 (sepuluh) kali nilai Cukai yang seharusya dibayar. Pelanggaran sebagaimana dimaksud didalam ayat (1) yang dilakukan untuk pertama kalinya dikenakan sanksi administrasi sebesar 2 (dua) kali nilai Cukai yang seharusnya dibayar. Apabila sanksi administrasi sebagaimana dimaksud dalam ayat (2) tidak dilunasi setelah lewat waktu yang ditentukan, maka atas pelanggaran tersebut dipidana sebagaimana dimaksud didalam ayat (1).

Sebagai salah satu bentuk hukum pidana administrasi, Undang-Undang Cukai menjadikan pidana sebagai cara untuk memaksakan kepatuhan bagi masyarakat wajib Cukai untuk melakukan kewajiban secara benar. Oleh karena kejahatan di bidang Cukai adalah kejahatan ekonomi yang selalu bermotif ekonomi atau bermotif mencari keuntungan (profit oriented). Maka senada dengan ahli ekonomi Gary Becker, pendekatan ekonomi menjadi suatu cara yang sangat baik dalam melakukan pencegahan maupun sebagai upaya untuk memberikan sanksi yang tepat. Menurut Gary Becker, pelaku kejahatan adalah orang-orang yang rasional yang selalu melakukan analisis tentang biaya dan keuntungan dalam menentukan apakah mereka akan melakukan atau tidak melakukan suatu kejahatan. Apabila biaya yang timbul lebih kecil dibandingkan dengan keuntungan atau resiko yang mungkin mereka hadapi, maka mereka akan melakukan pelanggaran atau kejahatan tersebut.

Hal ini juga senada dengan upaya untuk menerapkan suatu bentuk penegakan hukum yang berorientasi pada bagaimana mewujudkan keadilan restoratif. Perpaduan antara teori keadilan restoratif dan teori Social Cost merupakan jawaban yang tepat bagi penegakan hukum di bidang Cukai. Dengan pendekatan keadilan restoratif, kerugian Negara yang timbul dapat dipulihkan, sedangkan teori Social cost memberikan tekanan bagi pelanggar untuk mengurungkan niat dalam melakukan pelanggaran, karena biaya atau resiko yang mungkin timbul akan lebih besar dari keuntungan yang mungkin diperoleh.

Sejauh ini Undang-Undang Cukai belum menerapkan asas ultimum remidium dalam penegakan hukum pidana di bidang Cukai. Sanksi pidana seolah-olah menjadi premium remidium. Berbeda dengan Undang-Undang Nomor 32 tahun 2009 Tentang Lingkungan Hidup pasal 100 ayat (1) yang mengatur bahwa hanya jika sanksi administrasi yang dikenakan tidak diselesaikan oleh pihak yang melanggar, maka dianggap sebagai tindak pidana.

Demikian juga dalam Undang-Undang nomor 16 tahun 2009 Tentang Ketentuan Umum Dan Tata Cara Perpajakan pasal 13A dan pasal 38 yang mengatur bahwa suatu tindak pidana tidak dapat di pidana bilamana merupakan perbuatan yang dilakukan pertama kali. Disamping itu dalam ordonansi Cukai Gula Stbl. 1933 No. 351 terakhir disahkan sebagai Undang-Undang 1958 No. 76 (LN 1958 N0. 135) pasal 83 menyatakan bahwa: "untuk menghindari tuntutan pengadilan bagi semua tindak pidana dalam ordonansi ini, selama tidak dianggap sebagai kejahatan, maka Menteri Keuangan dapat berdamai atau menyuruh berdamai".Dalam ordonansi Cukai BIR 1931Stbl. 1931 No. 488 dan 489, diubah dengan ordonansi dalam Stbl. 1935 No. 502 pasal 30 menyatakan bahwa: "Menteri Keuangan dapat berdamai atau menyuruh berdamai untuk mencegah penuntutan di muka hakim mengenai semua pelanggaran".

Pelanggaran dalam ordonansi-ordonansi Cukai sepanjang tindak pidana tersebut bukan merupakan kejahatan dapat diselesaikan secara berdamai (Schikking) diluar sidang pengadilan (Soeparyono, 1992). Denda damai ini memberikan penegasan bahwa tujuan penegakan hukum dibidang Cukai adalah untuk mengumpulkan penerimaan Negara atau singkatnya untuk merestorasi kerugian Negara. Apabila langkah penyelesaian ini tidak dimungkinkan atau denda yang disepakati 
tidak terbayar, kemudian ketentuan pidana diterapkan.

Dalam Undang-Undang Cukai, diatur tentang upaya penyelesaian diluar pengadilan lewat mekanisme penghentian penyidikan oleh Jaksa Agung atas permintaan Menteri Keuangan. Perbedaan yang paling mencolok adalah bahwa ada pergeseran kewenangan yang semula menjadi kewenangan Menteri Keuangan, menjadi kewenangan Jaksa Agung. Catatan kritisnya adalah bahwa sebagai penuntut, tidak semestinya kewenangan menghentikan penyidikan berada pada Jaksa Agung, tetapi seharusnya kewenangan itu berada pada penyidik pegawai negeri sipil pada Direktorat Jenderal Bea dan Cukai yang memiliki kewenangan untuk melakukan penyidikan atas tindak pidana di bidang Cukai.

Dalam sistem peradilan pidana, penuntut umum (Jaksa) memiliki kewenangan untuk menentukan apakah suatu perkara hasil penyidikan sudah lengkap atau tidak untuk dilimpahkan ke pengadilan untuk diadili. Jika menurut pertimbangan penuntut umum suatu perkara tidak cukup bukti atau bukan merupakan suatu delik, maka penuntut umum membuat suatu ketetapan mengenai hal itu (Anwar, 2011). Ketetapan yang dimaksud adalah ketetapan mengenai penghentian penuntutan, bukan penghentian penyidikan.

Berdasarkan telaah dengan membandingkan antara ketentuan-ketentuan, memperhatikan praktik nyata yang dilakukan (best practice), penulis menganalisa bahwa rumusan pasal 64 UndangUndang Cukai, penulis menyarankan bahwa dimasa yang akan datang perlu dilakukan perubahan rumusan pasal tersebut sebagai berikut:

Kepentingan penerimaan Negara, atas permintaan menteri, Jaksa Agung dapat menghentikan penuntutan tindak pidana dibidang Cukai; Penghentian penuntutan tindak pidana di bidang Cukai sebagaimana dimaksud pada ayat (1), hanya dilakukan setelah yang bersangkutan melunasi Cukai yang tidak dan/atau kurang dibayar ditam- bah dengan sanksi administrasi berupa denda sebesar empat kali nilai Cukai yang tidak dan/atau kurang dibayar, atau Untuk kepentingan penerimaan Negara, atas permintaan menteri, Penyidik dapat menghentikan penyidikan tindak pidana dibidang Cukai. Penghentian penyidikan tindak pidana di bidang Cukai sebagaimana dimaksud pada ayat (1), hanya dilakukan setelah yang bersangkutan melunasi Cukai yang tidak dan/atau kurang dibayar ditambah dengan sanksi administrasi berupa denda sebesar empat kali nilai Cukai yang tidak dan/atau kurang dibayar. Penyidik memberitahukan hal itu kepada penuntut umum, tersangka atau keluarganya.

\section{Simpulan}

Melalui penelitian dan pembahasan yang telah disampaikan diatas, maka dapat disimpulkan bahwa penentuan suatu pelanggaran untuk dapat dikategorikan sebagai pelanggaran administrasi atau tindak pidana tidak lepas dari legalitas dari subyek hukum yaitu pengusaha BKC (barang kena cukai) maupun obyek hukum yaitu BKC (barang kena cukai) dan Pita Cukai. Bilamana salah satu dari subyek hukum atau obyek hukum bersifat ilegal, maka pelanggaran yang dilakukannya tersebut adalah suatu bentuk tindak pidana. Disamping sifat dari subyek hukum atau obyek hukumnya, suatu perbuatan yang dapat dipidana berdasarkan Undang-Undang Cukai apabila memenuhi kriteria antara lain dirumuskan secara tegas dan jelas sebagai pelanggaran, secara nyata menimbulkan kerugian Negara, dan merupakan perbuatan yang berulang, atau kerugian Negara yang ditimbulkan tidak dapat diperbaiki.

\section{Daftar pustaka}

Ablisar, Sarah Hasibuan Madiasa. 2015. Asas Ultimum Remedium Dalam Penerapan Sanksi Pidana Terhadap Tindak Pidana Perpajakan oleh Wajib Pajak. USU Law Journal, Vol.3.No.2. 


\section{Penerapan Asas Ultimum Remidium dalam Penegakan Hukum Pidana di Bidang Cukai \\ Indrawati \& Bendito Menezes}

Afif, Afthonul. 2015. Pemaafan, Rekonsiliasi dan Restoratif Justice. Jogjakarta. Pustaka Pelajar.

Ali, Mahrus. 2008. Penegakan Hukum Pidana Yang Optimal (Perspektif Analisis Ekonomi Atas Hukum). Jurnal Hukum No.2 Vol.15.

Ali, Mahrus. 2012. Dasar-dasar Hukum Pidana. Jakarta. Sinar Grafika.

Anwar, Yesmil. 2011. Sistem Peradilan Pidana. Jakarta. Widya Padjajaran.

Arief, Barda Nawawi dan Muladi. 1984. Teori-Teori dan Kebijakan Kriminal Bandung. Alumni.

Arief, Barda Nawawi. 1994. Kebijakan Legislatif dalam Penanggulangan Kejahatan dengan Pidana Penjara. Semarang. Badan Penerbit Universitas Diponegoro.

Arief, Barda Nawawi. 2001. Masalah Penegakan Hukum dan Kebijakan Penanggulangan Kejahatan. Bandung. Citra Aditya Bakti.

Arief, Barda Nawawi. 2002. Bunga Rampai Kebijakan Hukum Pidana. Bandung. Citra Aditya Bakti.

Asmarawati, Tina. 2014. Pidana dan Pemidanaan dalam Sistem Hukum di Indonesia. Jogjakarta. Deepublish.

Atmasasmita, Romli. 2010. Globalisasi dan Kejahatan Bisnis. Cetakan Ke-1. Jakarta. Kencana Prenada Media Group.

Dvannes. 2008. Restorative Justice Briefing Paper-2, Centre for Justice \& Reconciliation.

Hamzah, Andi. 2014. Asas Asas Hukum Pidana, Edisi Revisi, Jakarta. Rineka Cipta.

Hapsari, Indira. 2016. Kebijakan Hukum Pidana Dalam Upaya Penanggulangan Tindak Pidana Narkotika Pelaku Anak. Diponegoro Law Journal Volume 5, Nomor 3.

Kitab Undang-Undang Hukum Acara Pidana.

Kitab Undang-Undang Hukum Pidana.

Lewis, A. Kornhauser. 2000. On Justifying Cost and Benefit Analysis. Journal of Legal Studies. Vol. 29.

Mannheim. 1966. Comparative Criminoly, a textbook, vols. I and II. (London: $2^{\text {nd }}$ impression).
Marbun, Rocky. 2014. Rekonstruksi Sistem Pemidanaan dalam Undang-Undang Perpajakan Berdasarkan Konsep Ultimum Remidium. Jurnal Konstitusi, Volume 11, Nomor 3.

Marbun. 1978. Pokok - pokok Hukum Administrasi Negara. Jogjakarta. Liberty.

Marzuki, Peter Mahmud. 2011. Penelitian Hukum. Jakarta. Kencana Prenada Media Group.

Moeljatno. 2008. Asas Asas Hukum Pidana. Edisi Revisi. Jakarta. Rineka Cipta.

Muladi. Diah Sulistyani RS. 2016. Kompleksitas Perkembangan Tindak Pidana dan Kebijakan Kriminal. Bandung. Alumni.

Murtopo, Purno. 2011. Susunan Satu Naskah 7 (tujuh) Undang - Undang Kepabeanan dan Cukai Beserta Penjelasannya. Jakarta. Mitra Wacana Media.

Najih, Mokhammad. 2014. Politik Hukum Pidana, Konsepsi Pembaharuan Hukum Pidana dalam Cita Negara Hukum. Malang. Setara Press.

Posner, Richard. 1998. Economics Analysis of Law. edisi kelima. New York. Aspen Law \& Bussiness.

Prasetyo, Teguh. 2011. Kriminalisasi dalam Hukum Pidana. Bandung. Nusa Media.

Ridwan, H.R. 2014. Hukum Administrasi Negara. edisi revisi. Jakarta. Rajagrafindo Perkasa.

Saraswati, Putu Sekarwangi. 2015. Fungsi PidanaDalam Menanggulangi Kejahatan. Jurnal Advokasi Vol. 5 No.2.

Soekanto, Soerjono, dan Sri Mamudji. 2004. Penelitian Hukum Normatif. Cetakan ke-8. Jakarta. Raja Grafindo Persada.

Soekanto, Soerjono. 2012. Pengantar Penelitian Hukum. cetakan ketiga. Jakarta. UI Press.

Soeparyono. 1992. Analisa dan Evaluasi Tentang Cukai. Jakarta. Badan Pembinaan Hukum Departemen Kehakiman.

Sumaidi. 2014. Konsep Restorative Justice Terhadap AnakYang berkonflik Dengan Hukum. Jurnal Ilmiah Universitas Batanghari Jambi Vol.14 No.1.

Supanto. 2010. Kejahatan Ekonomi Global dan Kebijakan Hukum Pidana. Bandung. Alumni. 
Sutedi, Adrian. 2012. Aspek Hukum Kepabeanan. Jakarta. Sinar Grafika.

Tridiatno, Yoachim Agus. 2015. Keadilan Restoratif. Jogjakarta.Cahaya Atma Pustaka.

Undang-Undang RI Nomor 18 tahun 2016 tentang APBN tahun 2017 dalam LembaranNegara Republik Indonesia tahun 2016 Nomor 240.

Undang-Undang RI Nomor 16 tahun 2004 tentang Kejaksaan Republik Indonesia dalam Lembaran Negara Republik Indonesia Tahun 2004 Nomor 67.

Undang-Undang RI Nomor 16 Tahun 2009 sebagai perubahan atas Undang-Undang RI Nomor 6 Tahun 1983 tentang Ketentuan Umum dan Tata Cara Perpajakan dalam Lembaran Negara Republik Indonesia Tahun 2008 Nomor 211.
Undang-Undang RI Nomor 32 Tahun 2009 tentang Lingkungan Hidup dalam Lembaran Negara Republik Indonesia Tahun 2009 Nomor 140.

Undang-Undang RI Nomor 39 tahun 2007 sebagai perubahan atas Undang-Undang nomor 11 tahun 1995 Tentang Cukai dalam Lembaran Negara Repubilk Indonesia Tahun 2007 nomor 105.

Widodo. 2017. Prespektif Hukum Pidana dan Kebijakan Pemidanaan. Jogjakarta. Aswaja Pressindo.

William, L. Barnes Jr. 1999. Revenge on Utilitarianism: Renouncing A Comprehensive Economics Theory of Crime and Punishment. Indiana Law Journal. Vol. 74.

Zaidan, M. Ali. 2016. Kebijakan Kriminal. Jakarta. Sinar Grafika. 